\begin{tabular}{l|l|l|}
\cline { 2 - 3 } CRITICAL & $\begin{array}{l}\text { Western Ghats } \\
\text { PARTNERSHIP FUND }\end{array}$ & $\begin{array}{l}\text { Special Series } \\
\text { Pester }\end{array}$ \\
\hline
\end{tabular}

\section{MOOLAH, MISFORTUNE OR SPINSTERHOOD? THE PLIGHT OF SLENDER LORIS LORIS LYDEKKERIANUS IN SOUTHERN INDIA}

\author{
Arun Kanagavel ${ }^{1}$, Cynthia Sinclair ${ }^{2}$, Rajkumar Sekar ${ }^{3}$ \& \\ Rajeev Raghavan ${ }^{4}$ \\ ${ }_{1,3,4}$ Conservation Research Group (CRG), St. Albert's College, Cochin, Kerala \\ 682018 , India \\ ${ }_{1,2}$ Wildlife Information Liaison Development Society (WILD), ${ }^{4}$ Zoo Outreach \\ Organization, \\ 96, Kumudham Nagar, Vilankurichi Road, Coimbatore, Tamil Nadu 641035, India \\ ${ }^{1}$ arun.kanagavel@gmail.com (corresponding author), ${ }^{2}$ sinclair.cynthia@gmail. \\ com, ${ }^{3}$ raajkumar_seker@yahoo.com, ${ }^{4}$ rajeevraq@hotmail.com
}

The Slender Loris Loris lydekkerianus is a shy, smallsized primate, endemic to southern India and Sri Lanka (Kumara et al. 2006; Nekaris et al. 2008). It is a Least Concern species as per the IUCN Red List and is classified under Schedule I (Part I) of the Indian Wildlife Act, 1972 (Nekaris et al. 2008). Represented by two subspecies in India (lydekkerianus and malabaricus), this insectivorous primate is characterized by its huge, prominent eyes that assist in its nocturnal behavior (Kumara et al. 2009). Loris lydekkerianus lydekkerianus is the larger of the two subspecies, grey in color and found largely in plantations, villages or cultivated areas, especially in Acacia trees (Kumara et al. 2006). They are distributed across the Eastern Ghats, and also the eastern slopes of the Western Ghats (Radhakrishna et al. 2011). Loris lydekkerianus malabaricus is reddish-brown in color and restricted to the western slopes of central and southern Western Ghats (mostly at elevations above $700 \mathrm{~m}$ ) in Karnataka, Kerala and Tamil Nadu (Kumara et al. 2006, 2009; Radhakrishna et al. 2011). It prefers plantations and evergreen scrub forests within the broad

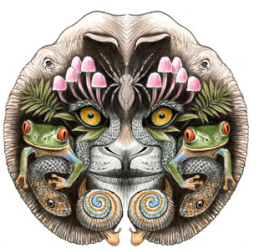

ISSN

Online 0974-7907 Print 0974-7893

\section{OPEN ACCESS} vegetation type of wet evergreen forests, and is also more abundant in disturbed areas (Kumara et al. 2006; Radhakrishna et al. 2011). In spite of several studies (Kumara et al. 2006, 2009; Radhakrishna et al. 2011), the distribution and threats to Slender Lorises are not well known from many regions in southern India.

This note contributes a new distribution record, and discusses poorly documented threats to Loris lydekkerianus in the southern Western Ghats. Our results originate from opportunistic observations, analysis of images from an Indian wildlife photography website and local knowledge-based surveys conducted at Peppara Wildlife Sanctuary (PWS), Kerala, during April 2011, as part of a project on the status of forest-dwelling chelonians in the Agasthyamalai Hills.

Interactions with the indigenous Kani community at Kanithadam inside PWS revealed the occurrence of a loris population close to the forest check post. Accompanied by individuals from this indigenous community, opportunistic visual encounter surveys were undertaken at night (1900$2330 \mathrm{hr}$ ) by members of our project team over a period of five days. A total of seven L.I. lydekkerianus sightings were made (Image 1 ; day $1=3$, day $2=$ nil, day $3=3$, day 4=1 and day 5=nil). The elevation here, ranged between

DOI: http://dx.doi.org/10.11609/JoTT.o3265.948 | ZooBank: urn:Isid:zoobank.org:pub:9AC1CA91-97CF-46B7-91A7-F6DF1F0D2500

Editor: Mewa Singh, Mysore University, Mysore, India.

Date of publication: 26 January 2013 (online \& print)

Manuscript details: Ms \# 03265 | Received 22 July 2012 | Final received 22 November 2012 | Finally accepted 05 December 2012

Citation: Kanagavel, A., C. Sinclair, R. Sekar \& R. Raghavan (2013). Moolah, misfortune or spinsterhood? The plight of Slender Loris Loris lydekkerianus in southern India. Journal of Threatened Taxa 5(1): 3585-3588; doi:10.11609/JoTT.03265.948

Copyright: @ Kanagavel et al. 2013. Creative Commons Attribution 3.0 Unported License. JoTT allows unrestricted use of this article in any medium, reproduction and distribution by providing adequate credit to the authors and the source of publication.

Funding: Rufford Small Grants Foundation (9190-1)

Competing Interest: None

Acknowledgements: We thank the Kani community and the officials of the forest check post at Kanithadam, Peppara Wildlife Sanctuary, Kerala; Varun Vikraman and Arjun Chincoli for helping with surveys; Aditya Prithvi for his suggestions on earlier versions of the manuscript and Ramnath Chandrashekar for lending his camera equipment. The authors thank the two anonymous reviewers and the Subject Editor for their comments and suggestions which greatly improved this note. The study was conducted with official permission from the Department of Wildlife and Forests, Kerala (WL 12-7326/2010).

The publication of this article is supported by the Critical Ecosystem Partnership Fund (CEPF), a joint initiative of l'Agence Française de Développement, Conservation International, the European Commission, the Global Environment Facility, the Government of Japan, the MacArthur Foundation and the World Bank. 


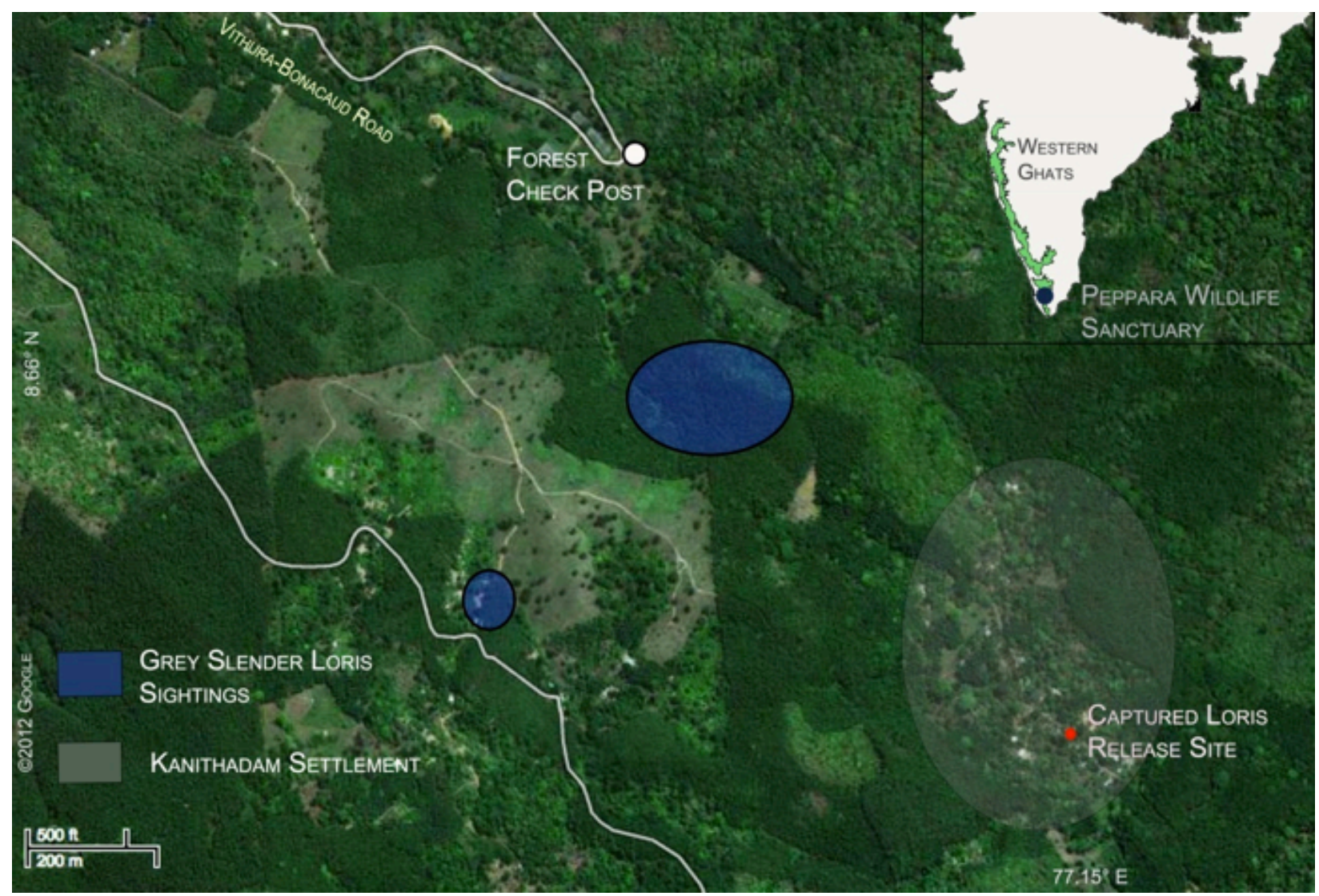

Image 1. Map of the study area at Peppara Wildlife Sanctuary with sighting records and release site of captured Loris lydekkerianus lydekkerianus.

158-208 $\mathrm{m}$ while the vegetation was largely bamboo Ochlandra sp. and plantations of Acacia and Eucalyptus. Currently L.I. lydekkerianus is known to be distributed across the Eastern Ghats and the eastern slopes of the Western Ghats and, L.I. malabaricus across the Western Ghats (Kumara et al. 2009, Fig 1., p.32). The southernmost point of occurrence of L.I. lydekkerianus according to available literature (CDL 2003; Kumara et al. 2009) is the Dindigul District of Tamil Nadu. Our sightings in PWS therefore, extends the range of L.I. lydekkerianus further south, by approximately $180 \mathrm{~km}$ to the Agasthyamalai Hills.

Subsequently, informal interviews were conducted with 12 Kani respondents to understand local attitudes as well as ecological knowledge of the species (Kanagavel \& Raghavan 2012). Locally known as 'tevaang', two types of lorises were perceived to occur at PWS, one distinctly larger and fairer in color while the other, smaller and brown in color. Known to be nocturnal, the Kanis had noticed them more frequently in the night from the glare reflected by the loris' eyes while using a torch. Lorises usually remain at a height of $4.5-5.5 \mathrm{~m}$ on trees, and are known to sometimes move on the ground. They consume tender parts of leaves especially that of bamboo, as well as insects, and are known to subsist on water collected within the cavities in the vegetation. Lorises are neither consumed nor kept as pets as the local community does not like their physical appearance. These animals are also perceived to bring bad luck, and if encountered in the forest means that locals will not find any nontimber forest produce in the area. Lorises also resemble their 'Mala Daivam' (Hill God), which also associates the species with religious sentiments. Unmarried women in the community are not allowed to, and also willingly abstain from seeing the species due to the belief that a sighting can lead to lifelong spinsterhood.

Accounts of local perceptions towards lorises are largely unavailable from India. Kumara (2007) documented the association of lorises as an omen in protected areas in Karnataka, which resulted in locals killing them when encountered. In Sri Lanka, the species is associated with similar beliefs; however their use for treating a variety of ailments from leprosy to preparing love potions is more prominent (Nekaris et al. 2010). The practice of collecting tears from lorises for treating eye ailments, although known to be popular in Tamil Nadu (Singh et al. 1999) 


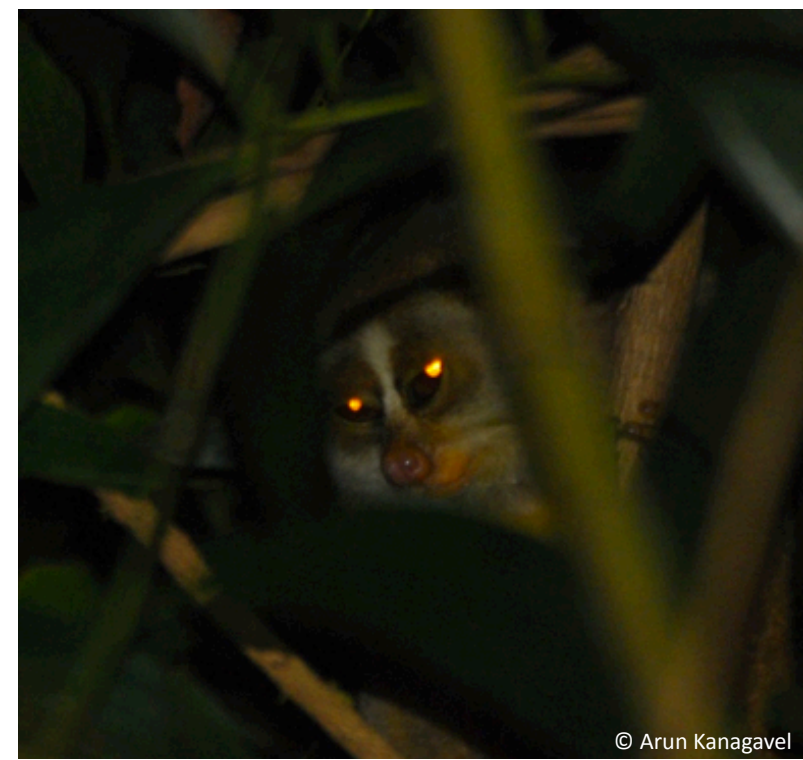

Image 2. Loris lydekkerianus lydekkerianus encountered during the surveys.

and Sri Lanka (Nekaris et al. 2010) is currently not in much practice at PWS.

During our study period, individuals of the Kani community captured an adult male L.I. lydekkerianus from an Acacia tree at night. The loris was collected for wildlife photographers from Thiruvanthapuram, located $40 \mathrm{~km}$ away, to indulge in photography. Our team was invited to see the animal, which was readily held on a short branch with torches aimed to highlight it, and prodded in order to refrain it from moving; so as to assist in capturing a "good" image (Image 3). The Kanis explicitly showed us various framing angles while photographing it. The animal was subsequently kept within a local's house and photographed by the photographer it was intended for, next morning. Subsequently the animal was released into an isolated bamboo thicket right next to the house, which had no vegetation continuity to the collection site (Image 1). The loris was not sighted the night after.

These locals were generally paid 500-1500 Indian Rupees by photographers for such 'managed photoshoots'. A respondent recounted that he had once collected an adult female loris with an infant, and also showed us an image given to him of the same. Another described to us that he had to cut down four trees in order to restrict a loris to a single tree to prevent it from escaping. They are supposedly easier to capture when they are at lower branches of trees, and respondents recounted painful bites while handling them. Lorises were known to be thus collected and kept within local settlements, generally covered by a cloth to avoid being seen by their women. Although, they are known to acclimatize to human

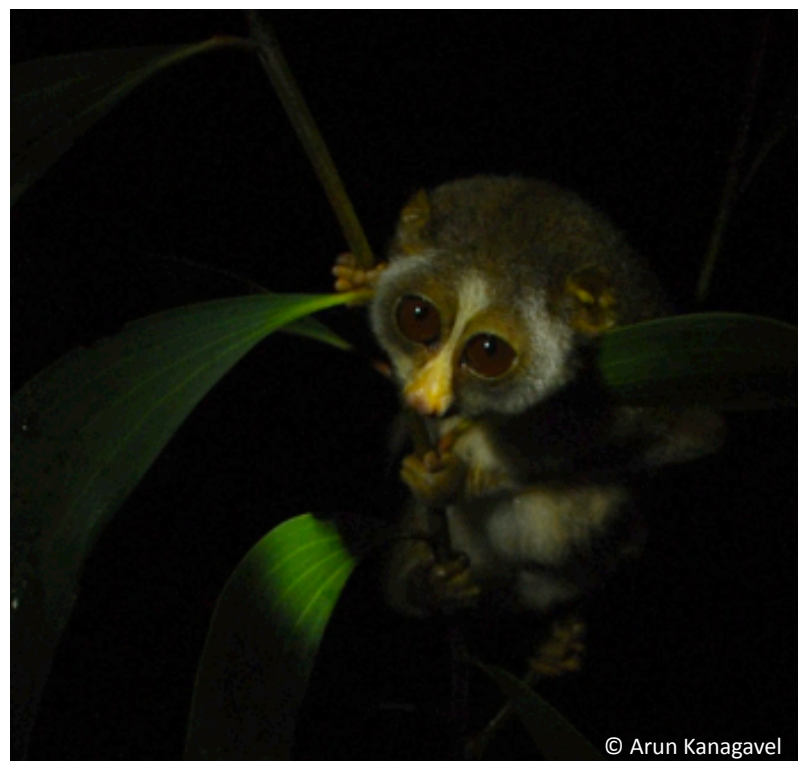

Image 3. The captured loris lydekkerianus lydekkerianus, photographed as per inputs of the indigenous locals.

company within two or three days, they are difficult to maintain as pets due to their daily requirement of tender leaves and insects, which are laborious to collect. The indigenous respondents have also sighted feral/domestic dogs killing these primates.

Unlike at PWS, slender lorises have been extensively sold as pets, and supplied to zoos in the states of Andhra Pradesh, Karnataka, Maharashtra, Tamil Nadu, and various other places in Kerala (Singh et al. 2000; Ahmed 2001). Also, local astrologers in Karnataka and Kerala are known to use lorises to pick out tarot cards (Ahmed 2001).

To find out whether the photography of lorises indeed involved unethical handling, India's prominent wildlife photography website, India Nature Watch (INW) (http:// www.indianaturewatch.net) which allows its users to post images online, was searched for related images. Images of slow lorises were omitted and only those of slender lorises were retained until the year, 2011. Multiple images posted by the same photographer from the same sighting were considered as a single event. Overall, 29 events, mostly from Karnataka $(n=20)$ followed by Tamil Nadu $(n=7)$ and Kerala $(n=2)$ were found, of which three were L.I. malabaricus, the rest being L. I. lydekkerianus. The two subspecies were identified and distinguished based on their overall body color and the circumlocular patch (Kumara et al. 2006).

The images of L.I. lydekkerianus were from Karnataka (Bengaluru, Chamrajnagar, Coorg, Tumkur) and Tamil Nadu (Dindigul, Kalakad-Mundanthurai Tiger Reserve, Krishnagiri, Sathyamangalam), while those of L.I. malabaricus were from Karnataka (Udupi) and Kerala 


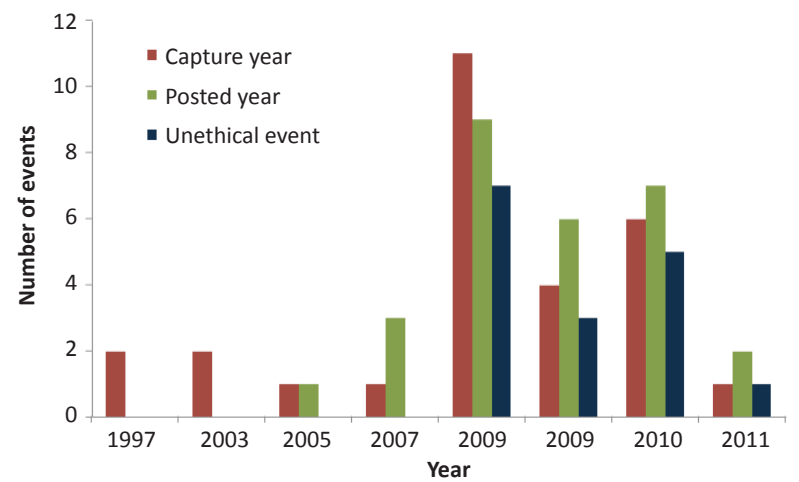

Figure 1. Capture and posted years of unethical Loris lydekkerianus events on the India Nature Watch website.

(PWS, Wayanad). A 'boom and bust' cycle is very evident as events captured during 1995 were posted beginning 2005, that could have eventually led to a peak in 2008, subsiding thereafter (Fig. 1). Images from INW substantiate the ecological knowledge of the Kanis that L.I. malabaricus also occurs at PWS. This suggests that the distribution of the two subspecies may overlap contrary to previous information (CDL 2003; Kumara et al. 2009), and yet remain isolated locally, by factors like elevation and vegetation. Images from INW also suggest new records for L.I. lydekkerianus at Coorg, Krishnagiri and Sathyamangalam.

One of the L.I. lydekkerianus photographed from Tumkur, Karnataka involved rescue and release by the forest department, and therefore this event was omitted from further review. Using our experience from PWS, we analyzed 28 events for instances during which lorises were captured and/or handled for photography. Ethical wildlife photography involves animals not being mistreated for acquiring an image. This ethic was not followed in a majority of cases $(n=16)$ and in one case a loris was held by its hind limb on the ground to restrict it from moving. In spite of largely being a nocturnal animal, 13 events were during the day. Two of the L.I. lydekkerianus photographed in Karnataka had infants.

Such unethical photography not only endangers a species protected under the Indian Wildlife Act (1972), but also promotes cultural and emotional discomfort among local communities, whose proximity to wildlife only presents an increased risk to wildlife conservation in this case. The process also involves tree felling and causes considerable amount of stress for the animal. Handling and/or capture of animals should be strongly discouraged, and instead loris watching and photography workshops could be organized in collaboration with local communities and the forest department. Wildlife photography based online initiatives like India Nature Watch (INW), set up to explore and promote the wildlife of India, should impose on its users such ethics, restrict it's members from posting such images and should also report to authorities of malpractices. Such guidelines currently exist for nesting birds and this should be extended for various other species, including lorises. Initiatives also need to be undertaken to promote ethical photography, especially in Karnataka, where the majority $(n=13)$ of unethical events occurred.

Urgent field surveys are also required in southern Kerala, northwestern Tamil Nadu and northern Karnataka to comprehensively understand the distribution and status of the various subspecies of Slender Loris in the Western Ghats. Such surveys would benefit from collaboration with online photography websites and citizen science initiatives like INW, which have resulted in an improved understanding of species distribution as demonstrated here.

\section{REFERENCES}

Ahmed, A. (2001). Illegal trade and utilization of primates in India. Envis Bulletin: Wildlife and Protected Areas 1(1): 177-184.

CDL (2003). Distribution of Slender Loris subspecies. www.lorisconservation.org/database/distribution_maps/02 Loris. html\#lydekk. Accessed on 9 November 2012. (Conservation database for lorises (Loris, Nycticebus) and pottos (Arctocebus, Perodicticus), prosimian primates)

Kanagavel, A. \& R. Raghavan (2012). Local ecological knowledge of the threatened Cochin Forest Cane Turtle Vijayachelys silvatica and Travancore Tortoise Indotestudo travancorica from the Anamalai Hills of the Western Ghats, India. Journal of Threatened Taxa 4(13): 3173-3182.

Kumara, H.N. (2007). Impact of local hunting on abundance of large mammals in three protected areas of the Western Ghats, Karnataka. National Institute of Advanced Studies, Bangalore.

Kumara, H.N., M. Irfan-Ullah \& S. Kumar (2009). Mapping potential distribution of Slender Loris subspecies in peninsular India. Endangered Species Research 7: 29-38.

Kumara, H.N., M. Singh \& S. Kumar (2006). Distribution, habitat correlates and conservation of Slender Loris, Loris lydekkerianus in Karnataka. International Journal of Primatology 27(4): 941-969.

Nekaris, A., M. Singh \& K.A. Chhangani (2008). Loris lydekkerianus. IUCN Red List of Threatened Species. Version 2011.2. www. iucnredlist. org. Accessed on 12 June 2012.

Nekaris, K.A.I., C.P. Shepherd, C.R. Starr \& V. Nijman (2010). Exploring cultural drivers for wildlife trade via an ethnoprimatological approach: a case study of Slender and Slow lorises (Loris and Nycticebus) in South and Southeast Asia. American Journal of Primatology 72: 877-886.

Radhakrishna, S., H.N. Kumara \& R. Sasi (2011). Distribution patterns of Slender Loris subspecies (Loris lydekkerianus) in Kerala, southern India. International Journal of Primatology 32(4): 1007-1019.

Singh, M., D.G. Lindburg, A. Udhayan, M.A. Kumar \& H.N. Kumara (1999). Status survey of Slender Loris Loris tardigradus lydekkerianus in Dindigul, Tamil Nadu, India. Oryx 33(1): 31-37.

Singh, M., M.A. Kumar, H.N. Kumara \& S.M. Mohnot (2000). Distribution and Conservation of slender lorises (Loris tardigradus lydekkerianus) in southern Andhra Pradesh, south India. International Journal of Primatology 21(4): 721-730. 